gurgle of the creek can be heard in the still air.

As the moon rises, a Horned Owl hoots in the distance, and the laughter of the Loons drifts across the water. A fox's sharp bark comes from the brush: a coyote yaps - and from far back in the hills comes the long mournful howl of a timber wolf then silence.

So ends a day at Fishing Lake, a nature lover's paradise.

\section{Trumpeter Swans}

Mrs. Percy Drury, Swift Current

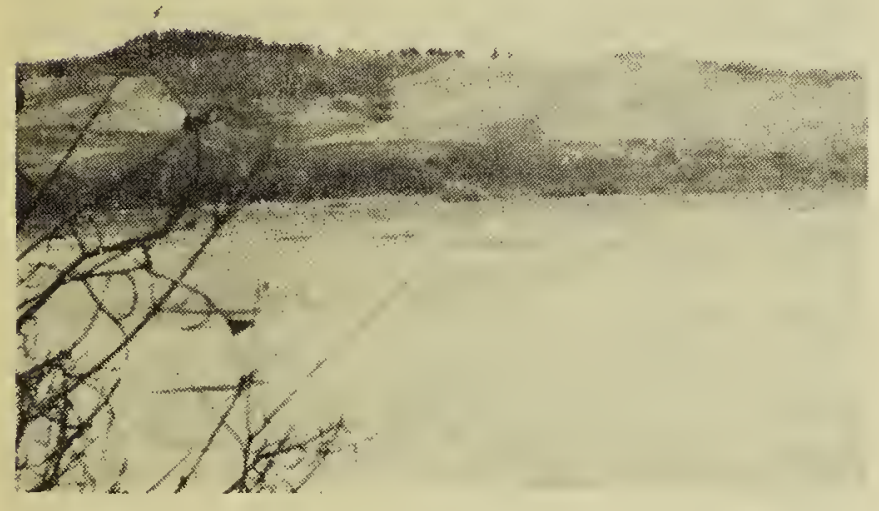

I was very interested that the beautiful birds on Adams Lake had been definitely identified by Mr. Bard as Trumpeter Swans. They have been nesting on Bottley's Lake for five years, always moving the young ones up to Adams Lake before they could fly. Later they often took them up another three miles to Harris' Lake. The accompanying photograph was taken in October, 1948. There was ice on the lake and they were quite a distance out. Later they came up to within 25 yards of me, apparently curious. Unfortunately my film was all used up.

One cold spring they raised no young ones but the next had three as if in a measure to compensate for the year before. Usually they seem to have only two. I wished many times I could have taken a color picture of these beautiful white birds on the blue water of Harris' Lake with the green and pale yellow poplar and the red and orange of Saskatoon and rose for a background. It made a lovely picture.

\section{A Conservation League Needed}

Ed Robinson, Wawanesa, Man.

Last year we had a failure of acorns in Manitoba and not one Blue Jay was seen here, whereas some winters I have counted as many as 18 at one time. I would be interested to know if they moved to other places, and where.

Birds are becoming very scarce in the thickly settled portions of Manitoba, to an alarming degree. I would like to know what others think of my idea of a Conservation League of Canada - from coast to coast with the sole idea of helping our wild life.

We now have many conservation organizations, but each has some specific aim. Ducks Unlimited is for sport - this is no reflection on the good they are doing. Provincial governments manage wildlife for revenue and political gain. I think it is high time we had an organization solely for the protection and increase of our wild life, so we may see it unspoiled in its natural setting.

\section{Arctic Three-toed Woodpecker}

JOYCE GUNN, Spirit Lake, Sask.

The beginning of April this year brought to our window-ledge feeding tray the first Arctic Three-toed Woodpecker (Black-backed woodpecker) that we have seen. It landed below the tray and started feeding on the crumbs the regular boarders, the chickadees and downy woodpeckers, had dropped. It seemed very tame and we were able to peer through the window at it and compare it to the illustrations in the bird book at our leisure as it did not fly until it had cleaned up all the crumbs and that took it a good five minutes. And it then only flew as far as the nearest tree where it sat for another ten or fifteen minutes allowing us to get another look at it through the binoculars. 